Rissaphop Treesuwan, Tanes Tanitteerapan

Thailand

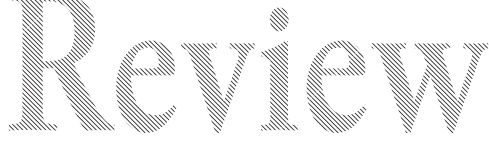

\title{
Students' Perceptions on Learner-Centered Teaching Approach
}

DOI: 10.15804/tner.2016.45.3.12

\begin{abstract}
There is growing evidence that the traditional "instruction-centered approach" to learning is not producing the desired learning outcomes in students. Many institutions of higher education in Thailand make it their main thrust to enable their students to become critical, independent thinkers and have the sense of ownership in the learning process. Most schools have shifted the focus in the classroom from conventional teaching to facilitating effective learning. This study centered on the impact of adopting the "learner-centered approach." Fifty students studying Industrial and Logistics Management at North Bangkok University took part in the assessment. The case study method was utilized and quantitative as well as qualitative data were generated with the use of a questionnaire and semi-structured interviews. Findings revealed that the implementation of "Learner-Centered Education" enhanced the learning outcomes and contributed to the attainment of quality education for the university.
\end{abstract}

Keywords: learner-centered teaching approach, students' perceptions, learning outcomes, independent thinkers, quality education

\section{Introduction}

Over the past few decades, there has been an increasing interest in developing teaching methods to involve students in the learning process under the influence of the constructivist learning theory (Hannafin et al., 1997). This concept defines 
learning as an "active process in which learners are active sense makers who seek to build coherent and organized knowledge" (Mayer, 2004). Within this premise, the model views learning as an active process of knowledge construction rather than as passive reception of information (Mayer, 2004; Tynjala, 1999). The general hypotheses for the constructivist teaching methods are described as "student-centered" teaching methods since they emphasize students' active role in the learning process (Elen et al., 2007; Loyens and Rikers, 2011).

Many universities, including North Bangkok University (NBU), Bangkok, Thailand, are trying to create curricula that are learning and student-centered. The emphasis is now more on paradigm shift to the constructivist approaches of teaching that are student-centered, away from behaviorist approaches that are teacher-centered (Schmittau, 2004). The context for the case study involves the students enrolled in the course of Industrial and Logistics Management.

Learner-centered teaching is an approach in which students have control over the learning process. In this situation, teachers do less talking and students do more discovering (Brown, 2008). The role of the instructor in the learner-centered approach is to design the course in such a way as to create a climate for optimal learning, to model the appropriate expected behavior for students, and to encourage students to learn from and with each other and provide more feedback throughout the process (Harpe and Phipps, 2009).

\section{Literature Review}

In a highly competitive global labour market, institutions of higher education are expected to produce graduates who are flexible, adaptable and prepared to take responsibility for their own learning as well continuous professional and personal development. A consequence of this move is the need to provide opportunities for students to develop a sense of ownership over their individual learning processes (Pedersen and Williams, 2004; Cavanagh, 2011). This is the underlying theory of the student-centered learning (SCL) approach.

Constructivism is a theory about knowledge and learning derived mainly from the work of Piaget and Vygotsky (Richardson, 2003). The main concept of constructivism is that human learning is constructed, and that learning builds new knowledge upon the foundation of previous learning (Prawat, 1996). Moreover, teachers and students engage in an in-depth exploration of important ideas from different subject matter domains (Prawat, 1996). In this situation, the teacher is responsible for delivering a predetermined instructional program 
using various techniques (Stipek, 2004). In behavioral classrooms, students are the recipients of knowledge, not participants in their own learning (Brooks and Brooks, 1993).

Recognizing the important value of the learner-centered teaching approach, there is growing evidence that higher education has increasingly accepted this as one of the innovative teaching approaches aimed at improving the quality of student experience and delivering better learning outcomes. The ultimate goal of the learner-centered teaching approach is to develop higher order thinking skills like comprehension, application analysis, synthesis and evaluation of knowledge instead of knowledge and recall of facts as proposed by Bloom (1956).

\section{Study Objectives}

This study sought to address the following questions:

1. What are the student's perceptions on the impact of adopting the learner-centered teaching approach in their course?

2. How effective are the strategies adopted by the school in relation to the implementation of the learner-centered teaching approach?

\section{The Course}

Lean Thinking Course is an undergraduate program offered by the Faculty of Industrial and Logistic Management, North Bangkok University, Bangkok, Thailand leading to the degree in Industrial and Logistic Management.

\section{Methodology}

The study used both quantitative and qualitative information. Education experts scrutinized and validated the content of the questions in the questionnaires. According to reliability test, each variable should not be less than 0.7 , whereas for test of validity, each variable used should not be less than 0.4 . Cronbach's alpha coefficient for internal consistency concerning the impact of the student-centered approach revealed that the dimensions for this construct demonstrated the acceptable alpha of 0.898 while that of the effectiveness of the teaching methodologies, the total scale presented the excellent consistency alpha of 0.90 . 


\section{Results and Discussion}

Out of ninety enrollees in the program, fifty participants were chosen and those students had been studying in the university for the past four or more years. Table 1 highlights the demographic profiles of the respondents.

Table 1. Profiles of the Respondents; $n=50$

\begin{tabular}{ccc}
\hline Student characteristics: & Frequency: & Percentage \\
\hline Gender: & & \\
\hline Female & 2 & $4 \%$ \\
\hline Male & 48 & $96 \%$ \\
\hline Nationality: & & \\
\hline Thai & 45 & $90 \%$ \\
\hline Foreigner & 5 & $5 \%$ \\
\hline Age: & & \\
\hline $17-19$ & 15 & $30 \%$ \\
\hline $20-22$ & 25 & $50 \%$ \\
\hline $23+$ & 10 & $20 \%$ \\
\hline GPA: & & \\
\hline $3.00-4.00$ & 46 & $92 \%$ \\
\hline $2.00-2.99$ & 4 & $8 \%$ \\
\hline & &
\end{tabular}

\section{Comparative Data Concerning Students' Perceptions on the Two Teaching Models}

The respondents strongly agreed $(\mu=3.28)$ that the learner-centered model enabled them to interact better with other students and teachers by sharing and discussing concepts related to classes. This was not the case when the teacher-centered approach was used. The mean of 1.77 indicated that the students disagreed that the impact on them was the same when their teachers controlled the whole learning process. Under the student-centered learning (SCL) model, the instructors assumed the role of resource persons, guides and coaches to probe and encourage the students to articulate their thoughts about the subject matter being tackled. This provided an avenue for the students to elaborate on the topic and interact better with peers and professors (Weimer, 2002).

The mean of 3.35 indicated that the respondents strongly agreed that the implementation of the learner-centered approach boosted their confidence in 
articulating their feelings and sentiments about a certain topic dealt with in the class discussion. The students did not feel this way when the teacher-centered instruction was used, as shown by the mean of 2.22, because most of the time it was the instructor who provided the information and the students were simply passive recipients of such data.

In terms of using various learning strategies, the respondents strongly agreed, as shown by the mean of 3.27, that in the student-centered learning model they can do it without restrictions. That was not the case in the teacher-centered model, as evidenced by the mean of 1.75. Generally, SCL as a constructivist learning approach places emphasis on the learner and propounds that learning is affected by their context, beliefs, attitudes and strategies (Mayer, 1998).

Here, the learner is encouraged to determine individual interpretation in addressing a given problem, which promotes the development of the learner's critical thinking skills (Von Glaserfeld, 1993; Parisi, 2006).

Table 2 shows the data concerning the students' perceptions on the two teaching models adopted by the Faculty of Industrial and Logistics, specifically for those who are pursuing the Bachelor's degree in Management.

Table 2. Students' Perceptions on Two Teaching Models, $\mathrm{n}=50$

\begin{tabular}{lcccc}
\hline \multicolumn{1}{c}{ Perceptions } & Teacher & $\begin{array}{c}\text { Centered } \\
\text { Int. }\end{array}$ & $\begin{array}{c}\text { Student } \\
\mu\end{array}$ & $\begin{array}{c}\text { Centered } \\
\text { Int. }\end{array}$ \\
\hline $\begin{array}{l}\text { 1. I can interact better with other students and } \\
\text { teachers by discussing concepts related to a class. }\end{array}$ & 1.77 & $\mathrm{D}$ & 3.28 & $\mathrm{SA}$ \\
\hline $\begin{array}{l}\text { 2. I am more confident in expressing my ideas about } \\
\text { a certain topic. }\end{array}$ & 2.22 & $\mathrm{D}$ & 3.35 & $\mathrm{SA}$ \\
\hline $\begin{array}{l}\text { 3. I can reflect on thoughts and theories to improve } \\
\text { my learning goals. }\end{array}$ & 2.55 & $\mathrm{~A}$ & 3.24 & $\mathrm{~A}$ \\
\hline $\begin{array}{l}\text { 4. My ability to understand and internalize the topic } \\
\text { presented was improved. }\end{array}$ & 2.00 & $\mathrm{D}$ & 3.26 & $\mathrm{SA}$ \\
\hline $\begin{array}{l}\text { 5. I am empowered to set my own learning objec- } \\
\text { tives. }\end{array}$ & 1.20 & $\mathrm{SD}$ & 3.25 & $\mathrm{~A}$ \\
\hline $\begin{array}{l}\text { 6. I can focus more on learning rather than just } \\
\text { getting a passing mark. }\end{array}$ & 2.20 & $\mathrm{D}$ & 3.28 & $\mathrm{SA}$ \\
\hline $\begin{array}{l}\text { 7. I was able to overcome test related anxieties. } \\
\text { 8. I can use various learning strategies without } \\
\text { restrictions. }\end{array}$ & 2.55 & $\mathrm{~A}$ & 3.30 & $\mathrm{SA}$ \\
\hline $\begin{array}{l}\text { 9. My critical thinking skills were enhanced to solve } \\
\text { course-related issues. }\end{array}$ & 1.69 & $\mathrm{D}$ & 3.29 & $\mathrm{DA}$ \\
\hline
\end{tabular}




\begin{tabular}{|c|c|c|c|c|c|c|}
\hline \multicolumn{3}{|c|}{ Perceptions } & $\begin{array}{c}\text { Teacher } \\
\mu\end{array}$ & $\begin{array}{l}\text { Centered } \\
\text { Int. }\end{array}$ & $\begin{array}{l}\text { Student } \\
\mu\end{array}$ & $\begin{array}{l}\text { Centered } \\
\text { Int. }\end{array}$ \\
\hline \multicolumn{3}{|c|}{$\begin{array}{l}\text { 10. I had sufficient feedback to guide me in my } \\
\text { learning journey. }\end{array}$} & 2.52 & A & 3.36 & SA \\
\hline Legend: & $\begin{array}{l}\text { Range } \\
3.26-4.00 \\
2.51-3.25 \\
1.76-2.50 \\
1.00-1.75\end{array}$ & $\begin{array}{l}\text { Interpretation } \\
\text { Strongly Agree (SA) } \\
\text { Agree (A) } \\
\text { Disagree (D) } \\
\text { Strongly Disagree (SD) }\end{array}$ & & & & \\
\hline
\end{tabular}

\section{Effectiveness of the Teaching Methodologies}

One learning strategy used by the faculty to create a student-centered learning environment was the adoption of a class project. This method was considered by the respondents as very effective in making the students become more active participants in their own learning process $(\mu=3.28)$. The required project called for the students to form into a group of 4-5 members.

Creation of a course council was another method used to promote student-centered learning. The respondents found this strategy effective $(\mu=3.24)$ in providing the students with the opportunities to learn from one another and fostering critical thinking and professional responsibility.

Table 3 shows the extent of effectiveness of the various teaching methodologies adopted by the instructors in the course of creating a learner-centered environment.

Table 3. Effectiveness of Teaching Methodologies, $n=50$

\begin{tabular}{llc}
\hline \multirow{2}{*}{ Type of teaching methodology } & \multicolumn{2}{c}{ Extent of Effectiveness } \\
\cline { 2 - 4 } & \multicolumn{1}{c}{$\boldsymbol{\mu}$} & Int. \\
\hline 1. Class project & 3.28 & $\mathrm{VE}$ \\
\hline 2. Creation of a Course Council & 3.24 & $\mathrm{E}$ \\
\hline 3. Self-paced Learning program & 3.30 & $\mathrm{VE}$ \\
\hline 4. Reflective learning & 3.23 & $\mathrm{E}$ \\
\hline 5. Management Project logbook & 3.40 & $\mathrm{VE}$ \\
\hline 6. Lectures, discussions & 1.80 & $\mathrm{LE}$ \\
\hline Legend: & Range & Interpretation \\
$3.26-4.00$ & Very Effective (VE) & \\
$2.51-3.25$ & Effective (E) & \\
$1.76-2.50$ & Less Effective (LE) \\
$1.00-1.75$ & Not Effective (NE)
\end{tabular}




\section{Conclusion}

The results of the case study showed clearly that the introduction of the learner-centered teaching approach in the BS program in Industrial and Logistics Management has greatly influenced and improved the students' learning process and widened the scope of their learning skills and knowledge. This model of learning provides an alternative to the conventional teacher-centered learning and enabled the students to enjoy a more meaningful learning environment.

\section{References}

Beijaard, D., Verloop, N. and Vemunt, J. (2000). Teachers' perceptions of professional identity: An exploratory study from a personal knowledge perspective. Teaching and teacher education, 16(7), 749-764.

Boud, D. (1990). Assessment and the promotion of academic values. Studies in Higher education, 15(2), 101-112. (Retrieved on May 3, 2015 from Academic Search premier).

Brooks, J.G. and Brooks, M.G. (1993). The case for constructivist classrooms. VA: ASDC.

Brown, J.K. (2008). Student centered instruction: Involving students in their own education. Music educators journal, 5(4), 36-42.

Candela, L., Dalley, K. and Benzel-Lindley, J. (2006). A case for learning centered curricula. Journal of nursing education, 45, 59-66.

Cavanagh, M. (2011). Students' experiences of active engagement through cooperative learning activities in lectures. Active Learning in Higher Education, 14(1), 55-69.

Elen, J., Clarebout, G., Leonard, R. and Lowyck, J. (2007). Student centered and teacher centered learning environments: What students think. Teaching in higher education, $12(1), 105-117$.

Gibbs, G. (1992). Improving student-centered learning project: Briefing paper for participants. Oxford, Oxford Center for Staff Development.

Hannafin, M., Hill, J. and Land, S. (1997). Student centered learning and Interactive multimedia: Status, issues and implications. Contemporary Education, 68(2), 94-99.

Harpe, S.E. and Phipps, L.B. (2008). Evaluating student perceptions of a learner centered during literature evaluation course. American journal of Pharmaceutical Education, $72(6), 1-7$.

Kirschner, P., Sweller, J. and Clark, R. (2006). Why minimal guidance during Instruction does not work: An analysis of the failure of constructivist, Discovery, problem-based, experiential and inquiry based teaching. Educational Psychologist, 41(2), 75-86.

Loyens, S. and Rikers, R. (2011). Instruction based inquiry. In R. Mayer and P. Alexander (Eds.) Handbook of research on learning and instruction. (pp. 361-381), N.Y.: Routledge.

Loyens, S., Rikers, R. and Schmidt, H. (2007). The impact of students' conceptions of 
constructivist assumption on academic achievement and drop out. Studies in higher education, 32(5), 581-602.

Mayer, R.E. (1998). Cognitive theory for education: What teachers need to know. In How Students Learn: Reforming Schools Through Learner-Centered Education, edited by Nadine M. Lambert and Barbara L. McCombs, American Psychological Association, Washington, D.C., pp. 353-377.

Mayer, R. (2004). Should there be a three strikes rule against pure discovery Learning? The case for guided methods of instruction. American Psychologist, 59(1), 14-19.

Miles, M.B. and Huberman, A.M. (1994). Qualitative data analysis. $2^{\text {nd }}$ ed., Thousand Oaks, CA: Sage Publications.

Motschnig - Pitrick, R. and Holzinger, A. (2002). Student centered teaching meets new media: Concept and case study. Educational technology and society, 5(4), 160-172.

Parisi, P.J. (2006). A transition study in digital media courses from directed study and faculty assessment to student controlled learning and self-assessment. Paper presented at the meeting of the International Digital Media Arts and Association, San Diego, CA.

Pedersen, S. and Williams, D.A. (2004). A comparison of assessment practices and their effects on learning and motivation in a student centered learning environment. Journal of Educational Multimedia and Hypermedia, 13(3), 283-306.

Pham Thihanh (2005). Learners' and teachers' performance for classroom activities. Essex University: Essex University Press.

Prawat, R.C. (1996). Constructivisms, modern and post-modern. Educational Psychologist, 31(3), 215-225.

Richardson, V. (2003). Constructivist pedagogy. Teachers college record, 105 (9), $1623-1640$.

Rust, C., Price, M. and O’Donovan, B. (2003). Improving students' learning by developing their understanding of assessment criteria and processes. Assessment and Evaluation in higher education, 28(2), 147-164.

Schmittau, J. (2004). Vygotskian theory and mathematics education: Resolving the conceptual - procedural dichotomy. European Journal of Psychology and Education, 19(1), 19-43. (retrieved Feb. 2015 from Academic Search Premier).

Shor, I. (1989). Developing student autonomy in the classroom. Equity and Excellence, 24(3), 35-37.

Stipek, d. J. (2004). Teaching practices in kindergarten and first grade: Different strokes for different folks. Early childhood research quarterly, 19, 548-568.

Struyven, K., Dochy, F. and Janssen, J. (2010). Teach as you preach: The effects of student centered versus lecture based teaching on student teachers' approaches to teaching. European journal of teacher education, 33(1), 43-64.

Tynjala, P. (1999). Towards expert knowledge? A comparison between a Constructivist and a traditional learning environment in the university. International journal of educational research, 31, 357-442.

Weimer, M. (2002). Learner centered teaching: Five key changes for practice. San Francisco, CA: Jossey Bass. 
Wilson, I. (1995). When we want to empower as well as teach. In K. Warren, M. Sakols, and

I. Hunt (Eds.). The theory of experiential education. $3^{\text {rd }}$ ed., pp. 275-283). Dubuque,IA: Kendall/Hunt.

Von Glaserfeld, E. (1993). Questions and answers about radical constructivism In Tobin, K. (Eds.), The practice of constructivism in science education. Hillsdale, NJ: Erlbaum Associates. 